\title{
Prediction of Dipole Moment $(\mu)$ for Aniline substituted, Calculation theory and ( QSPR) Techniques.
}

https://doi.org/10.32792/utq/utj/vol11/1/1

\author{
Kawkab A. Hussain \\ Department of Chemistry - College of Education Pure Science \\ University of Basrah - Iraq
}

\begin{abstract}
Calculated theory for dipole moment $(\mu)$, of aniline substituted have been conducted. The study was done by using molecular modeling. The calculation was performed by different methods PM3, PM6, and MP2 at 6-31G(d,p)basis set and predicted dipole moment ( $\mu$ ) by QSPR. The relationship analysis between dipole moment $(\mu)$, and physicochemical properties understudy was done by multiple linear regression (MLR) analysis to produce the equation that relates the structural features to the dipole moment $(\mu)$, properties. The results show good models with one and two parameters linear equations. The best model predicted in this study was the eq.6, with excellent statistical fit as evident from its $R^{2}=0.972, \quad F=41.455, \quad S=$ 0.329 , and $\mathrm{Ra}^{2}=0.949$, the model including the descriptors $[\log \mathrm{P}$, $\operatorname{surface}(A), \operatorname{surface}(\mathrm{G})$, T.E REF and E.GAP], which showed insignificant role in the dipole moment $(\mu)$, of compounds. And this could potentially offer a new opportunity in the design of novel properties or extended to other compounds.
\end{abstract}

Keywords. Aniline substituted, predicted dipole moment $(\mu)$, (QSPR) Model.

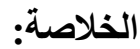

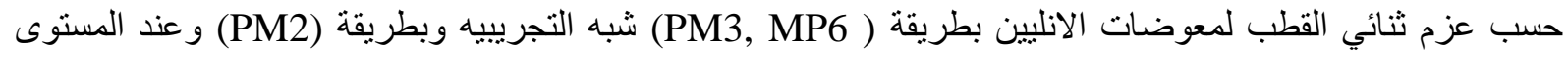

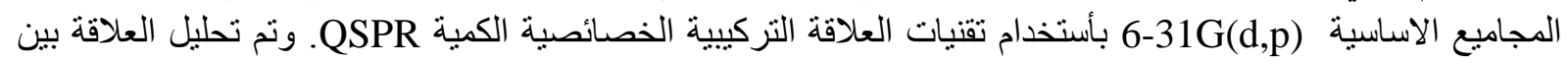

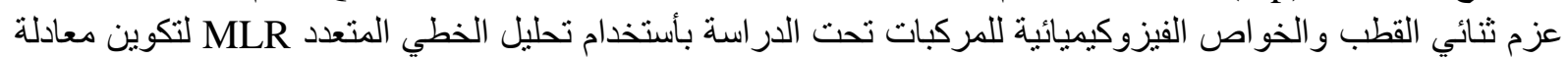

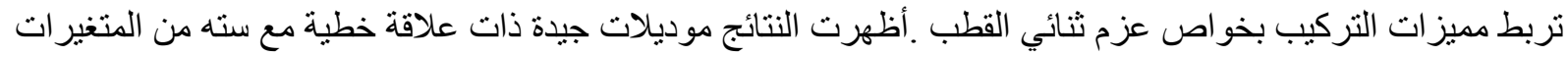

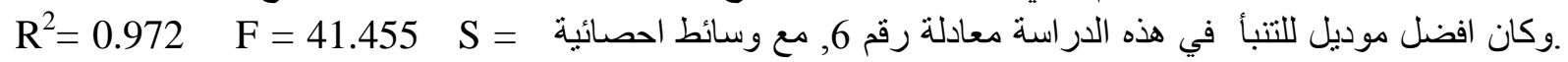
[LogP, surface(A), surface(G), T.E REF and الموديل تضمن الموصوفات 0.329 Ra و التي اظهرت دور مميز في التأثير على عزم ثنائي القطب. و هذه الدر اسات ممكن أن تقدم فرص حديثة لتصميم

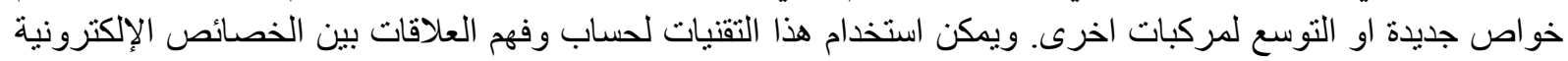
و التركيب الجزيئي ويمكن استخدامها لاستكثاف مدى ملاءمتها في تطبيقات مختلفة أيضا. 


\section{Introduction}

The physical properties of organic compounds such as dipole moment $(\mu)$, dielectric constant $(\boldsymbol{\varepsilon})$, solubility, melting point, and boiling point, density, viscosity, refractive index etc. are very much related to molecular interactions and plays a very important part in the processing of materials. These physical properties play important role in various applications in the field biological systems, industrial application. One of these physical property is dipole moment $(\mu)$, which is the measure of net molecular polarity, which is the magnitude of the charge at either end of the molecular dipole times the distance $r$ between the charges. Dipole moments tell us about the charge separation in a molecule. The larger the difference in electronegativities of bonded atoms, the larger the dipole moment. Dipole moment depends on three factors: polarity of molecule. magnitude of charge, geometry of molecule. And most important it has a significant effect on the properties and processing characteristics of the compounds[1-4].

Therefore to an understanding and obtain more information regarding the dipole moment $(\mu)$, behavior of aniline compounds, this work is undertaken, to study these properties by quantitative structure-property relationships (QSPRs) Which it represented a mathemat- ical models that attempt to relate the structure-derived features of a compound to its biological or physicochemical activity, it is tools to estimate physicochemical and biochemical parameters and reduce the coast, time and efforts. (QSPR/QSAR) study is an important section in computational chemistry and uses frequently for predicting physico - chemical and biological activity of organic compounds[5-6]. Application of quantitative structure-property relationship (QSPR) models in prediction and estimation of physical properties of materials is widely developing. In QSPR, advanced mathematical methods (Genetic algorithm, neural networks, and etc.) are used to find a relation between property of interest and the basic molecular properties which are obtained solely from the chemical structure of compounds and called "molecular descriptors"[7-12]. In this work we demonstrate the usefulness some of the parameters in deriving predictive QSPR models. The relation between the dipole moment $(\mu)$, and quantum chemical calculation parameters to know the physicochemical behavior of aniline substituted compounds, and to find out the effect of various the structural, chemical, physical and other properties of these compounds understudy on experimental dipole moment $(\mu)$.

\section{Modeling and Geometry Optimization}

The quantum chemical calculations were performed for 14 compounds understudy with the Gaussain [13]. Geometrical optimizations were carried out using at mp2 method at 6$31 \mathrm{~g}(\mathrm{~d}, \mathrm{p})$ level of theory[14]. The experimental dipole moment $(\mu)$ data of 14 aniline 
substituted compounds under study has been taken from reference[15]. Structures of 14 aniline substituted compounds shown in Figure.1 .

\begin{tabular}{|c|c|}
\hline No & $\mathrm{R}$ \\
\hline 1 & aniline \\
\hline 2 & 3-bromoaniline \\
\hline 3 & 4-bromoaniline \\
\hline 4 & o-chloroaniline \\
\hline 5 & m-chloroaniline \\
\hline 6 & o-nitroaniline \\
\hline 7 & p-nitroaniline \\
\hline 8 & o-toluidine \\
\hline 9 & m-toluidine \\
\hline 10 & p-toluidine \\
\hline 11 & n,n diethylaniline \\
\hline 12 & n,n diethyl-o-toluidine \\
\hline 13 & n,n diethyl-p-toluidine \\
\hline 14 & $\mathbf{N}$,methyl aniline \\
\hline
\end{tabular}

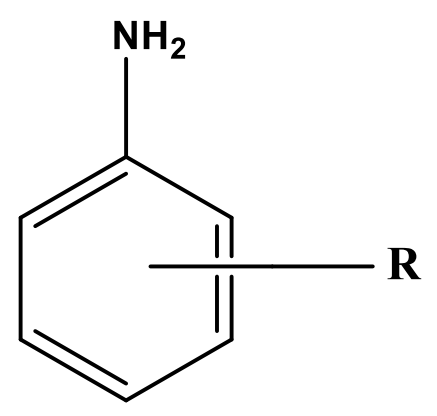

Figure 1. Molecular structure of compounds used in the present study

\section{Results and Discussion}

A full quantum mechanical geometry optimization was performed using Gaussian 03 computational program for calculation ., The dipole moment have been investigated for all compounds by different methods PM3, PM6, MP2 and build QSPR models depend on some descriptor calculated by MP2 method accordingly correlation it with the experimental value of dipole moment $(\mu)$. In the first the prediction model of QSPR study has been make up with assist of the next descriptors HOMO energy, LUMO energy, HOMO-LUMO energy gap $(\Delta \mathrm{E})$, Dipole moment $(\mu)$, charge, Total Energy, Hydration Energy, refractivety, LogP, volume, surface(A), surface $(G)$, can be directly related with experimental data of dipole moment. The 1 and 12- descriptor correlations of the dipole moment were given in eqs (1-6) respectively and the resulting parametric models are depicted in figures. 2-6, along with statistical parameters of the regression. 
University of Thi-Qar Journal Vol.11 No.1 Mar 2016

Web Site: https://jutq.utq.edu.iq/index.php/main Email: journal@jutq.utq.edu.iq

\begin{tabular}{rrrrrrcccccc} 
No & LUMO & HOMO & \multicolumn{1}{c}{ E.Gap } & \multicolumn{1}{c}{ T.E } & *pol & *Ref & *Log-p & *H.E & *Volum & *Surf(G) & *Surf(A) \\
\hline 1 & 4.1372 & -7.518 & 11.6552 & -286.706 & 11.79 & 34.51 & -0.12 & -7.47 & 366.44 & 257.94 & 209.8 \\
2 & 3.4839 & -8.2516 & 11.7355 & -2856.12 & 14.41 & 42.04 & -0.07 & 7.06 & 427.85 & 290.57 & 250.97 \\
3 & 3.5048 & -8.0396 & 11.5445 & -2856.12 & 14.41 & 42.04 & -0.07 & -7.18 & 427.75 & 290.57 & 252.2 \\
4 & 3.6781 & -7.8581 & 11.5363 & -745.733 & 13.71 & 39.22 & -0.34 & -6.44 & 404.75 & 278.64 & 233.75 \\
5 & 3.6773 & -7.9196 & 11.597 & -745.732 & 13.71 & 39.22 & -0.34 & -6.91 & 409.31 & 281 & 242.17 \\
6 & 1.4517 & -8.4755 & 9.9273 & -490.712 & 13.63 & 39.72 & -4.8 & -10.58 & 418.38 & 285.42 & 237.18 \\
7 & 1.7785 & -8.6619 & 10.4405 & -490.712 & 13.63 & 39.72 & -4.8 & -12.29 & 428.13 & 292.14 & 260.47 \\
8 & 4.125 & -7.7792 & 11.9042 & -325.897 & 13.62 & 38.79 & 0.03 & -5.73 & 413.09 & 279.99 & 235.29 \\
9 & 4.0463 & -7.8113 & 11.8577 & -325.896 & 13.62 & 38.79 & 0.03 & -5.99 & 418.07 & 286.31 & 248.28 \\
10 & 3.9728 & -7.6374 & 11.6103 & -325.896 & 13.62 & 38.79 & 0.03 & -6.3 & 418.43 & 284.53 & 250.72 \\
11 & 4.0262 & -7.644 & 11.6702 & -443.212 & 19.12 & 54.07 & 1.33 & -0.03 & 552.65 & 354.25 & 343.4 \\
12 & 3.9769 & -8.4941 & 12.471 & -482.603 & 20.96 & 58.35 & 1.49 & 0.87 & 603.99 & 378.67 & 358.5 \\
13 & 4.1465 & -7.1038 & 11.2503 & -482.589 & 20.96 & 58.35 & 1.49 & 1.17 & 604.51 & 380.99 & 386.51 \\
14 & 4.0354 & -7.7123 & 11.7477 & -325.882 & 13.62 & 39.28 & 0.29 & -4.38 & 420.11 & 287.62 & 263.78 \\
\hline
\end{tabular}

Table 1. Descriptors as the independent variables used for QSPR analysis of compounds

\section{Definition of Descriptors Used in This Study.}

$\Delta \mathrm{E}=$ Energy. GAP $=$ Different between $\mathrm{HOMO}$ and LUMO is energy gaps in eV, LUMO= The energy of Lowest Unoccupied Molecular Orbital in $\mathrm{eV}, \mathrm{HOMO}=$ The energy of Highest Occupied Molecular Orbital in $\mathrm{eV}, \mu$ = Dipole moment in debyes., H.E= Hydration Energy in $\mathrm{Kcal} / \mathrm{mol}$, Volume in $\mathrm{Ang}^{3}$, T.E $=$ Total Energy in a.u., Surface $(\mathrm{G})$, Surface $(\mathrm{A})=\mathrm{Cm}^{2}$, *Calculated by Hyperchem Software.

Physiochemical and alignment-independent were established by sequential multiple regression analysis (MLR) in order to obtain QSPR models. The best model was selected on the basis of statistical parameters viz observed with high correlation coefficient (R), sequential Fischer test $(\mathrm{F})$, adjusted coefficient of multiple determination $\left(\mathrm{Ra}^{2}\right)$, and low standard error of estimate (S), were employed to judge the validity of regression equation and evaluate the obtained QSPR models 


\section{University of Thi-Qar Journal Vol.11 No.1 Mar 2016}

Web Site: https://jutq.utq.edu.iq/index.php/main Email: journal@jutq.utq.edu.iq

The first model when depend on only one parameter [LUMO] gave model with correlation coefficient $\mathrm{R}^{2}$ values for this model of 0.831 , as equation 1 . The suggest that the dipole moment increases with increase values of this descriptor. And from this eq1, there is inverse relationship between LUMO and dipole moment.

D.M $=-1.546(+/-0.6143)$ LUMO+7.7968(+/-2.2545) $\ldots . . E q 1$

$\mathrm{R}^{2}=0.831 \quad \mathrm{~F}=59.05 \quad \mathrm{~S}=0.625 \quad \mathrm{Ra}^{2}=59.05$

The relationship between the experimental data and predicted dipole moment $(\mu)$ for aniline substituted as shown in Fig.2.

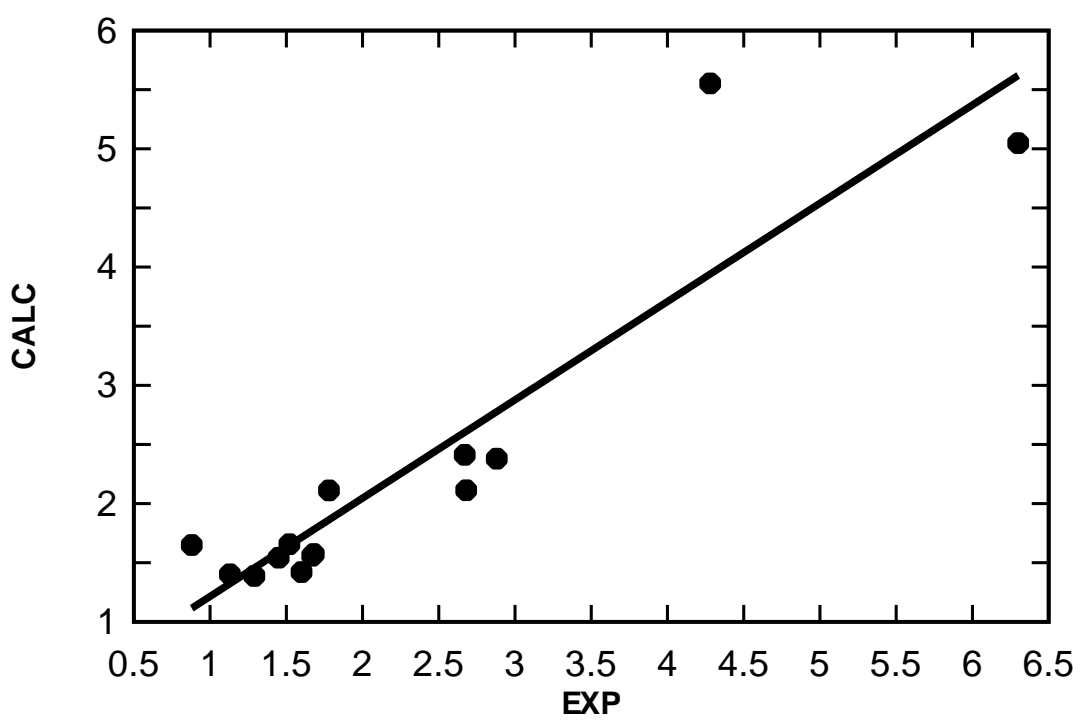

Figure 2. Plot of $(\mu)$ prediction versus $(\mu)$ experimental using Eq 1.

Second model eq2. of the dipole moment $(\mu)$, of aniline compounds increases with increase LUMO and T.E values.

D.M=7.591(+/-2.396)-1.530(+/- 0.629)LUMO-1.886X10 $0^{-4}\left(+/-6.142 X 10^{-4}\right)$ T.E....Eq2 $\mathrm{R}^{2}=0.844 \quad \mathrm{~F}=29.759 \quad \mathrm{~S}=0.627 \quad \mathrm{Ra}^{2}=0.815$

Fig 3. Show the relationship between the experimental data and dipole moment $(\mu)$. 


\section{University of Thi-Qar Journal Vol.11 No.1 Mar 2016}

Web Site: https://jutq.utq.edu.iq/index.php/main Email: journal@jutq.utq.edu.iq

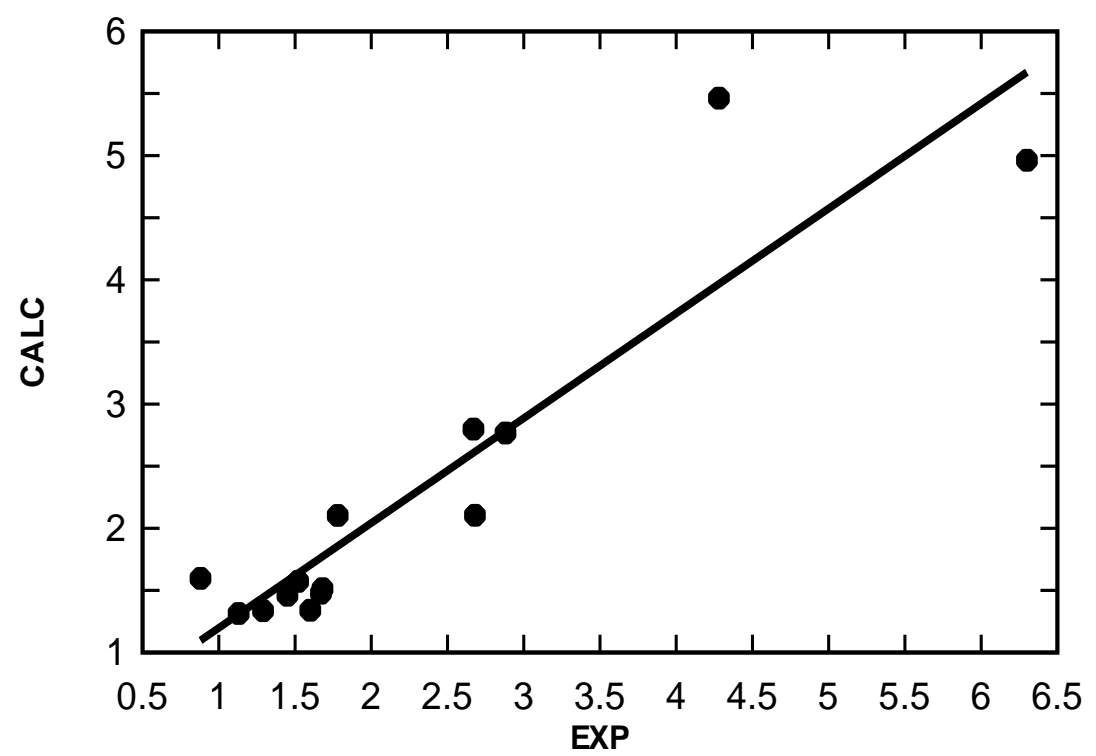

Figure 3. Plot of $(\mu)$ prediction versus $(\mu)$ experimental using Eq 2.

Three- parameter correlations of the anilne compounds were given in eq 3 .

D.M $=-0.398(+/-0.941)$ LOG P- 0.660(+/-2.147)T.E-3.016X104(6.614X10-

$\left.{ }^{4}\right)$ LUMO +4.224(+/-8.3003) $\ldots \ldots . . . \mathrm{Eq} 3$

$\mathrm{R}^{2}=0.867 \quad \mathrm{~F}=21.880 \quad \mathrm{~S}=0.606 \quad \mathrm{Ra}^{2}=0.828$

The relationship between the experimental data and predicted dipole moment $(\mu)$, are given in Fig.4.

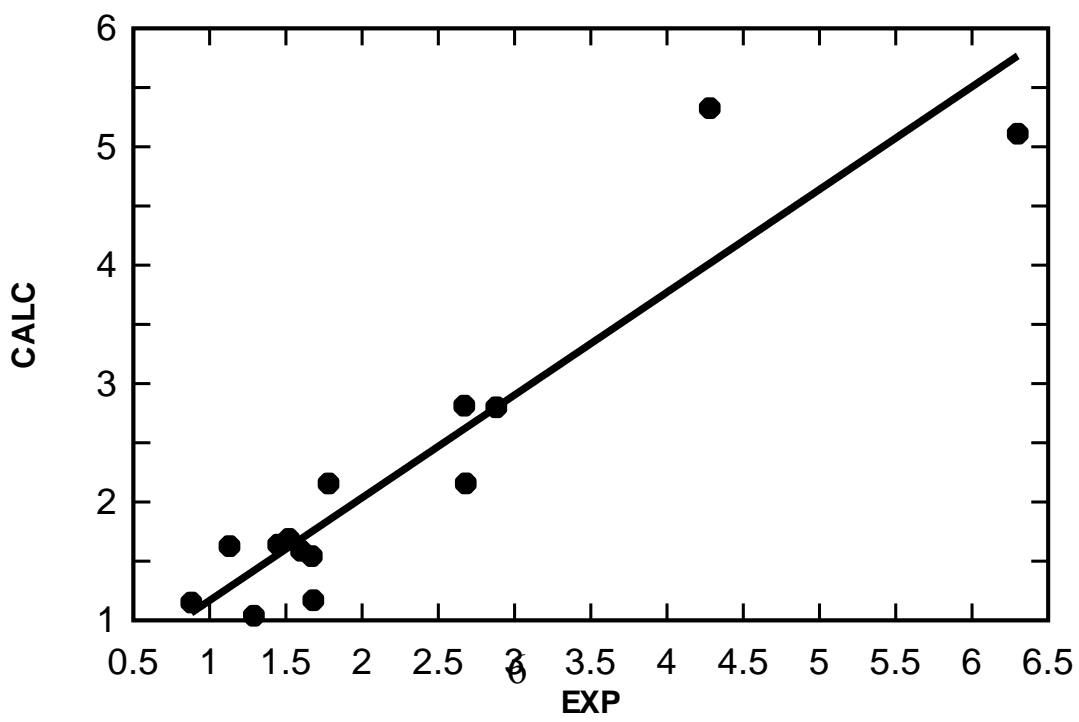


Figure 4. Plot of $(\mu)$ prediction versus $(\mu)$ experimental using Eq 3.

On other hand, when the depending on[ $\log P$, surface $(A)$, surface $(G)$ andT.E] . obtained on equation 4 . With the correlation coefficient 0.927 . As seen from this resulting in a very good improvement of the correlation coefficient, in contrast standard error highest and a decrease of the F-test statistic.

D.M $=-0.781 \%(+/-0.249) * \log \mathrm{p}+3.999 \times 10-2(+/-5.980 \times 10-2) \operatorname{surface}(\mathrm{A})-4.978 \times 10-4(+/-$

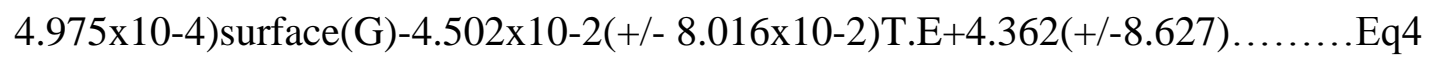

$$
\mathrm{R} 2=0.927 \quad \mathrm{~F}=28.992 \quad \mathrm{~S}=0.471 \quad \mathrm{Ra} 2=0.895
$$

Fig 5. Represents the relationship between the experimental data and predicted dipole $\operatorname{moment}(\mu)$.

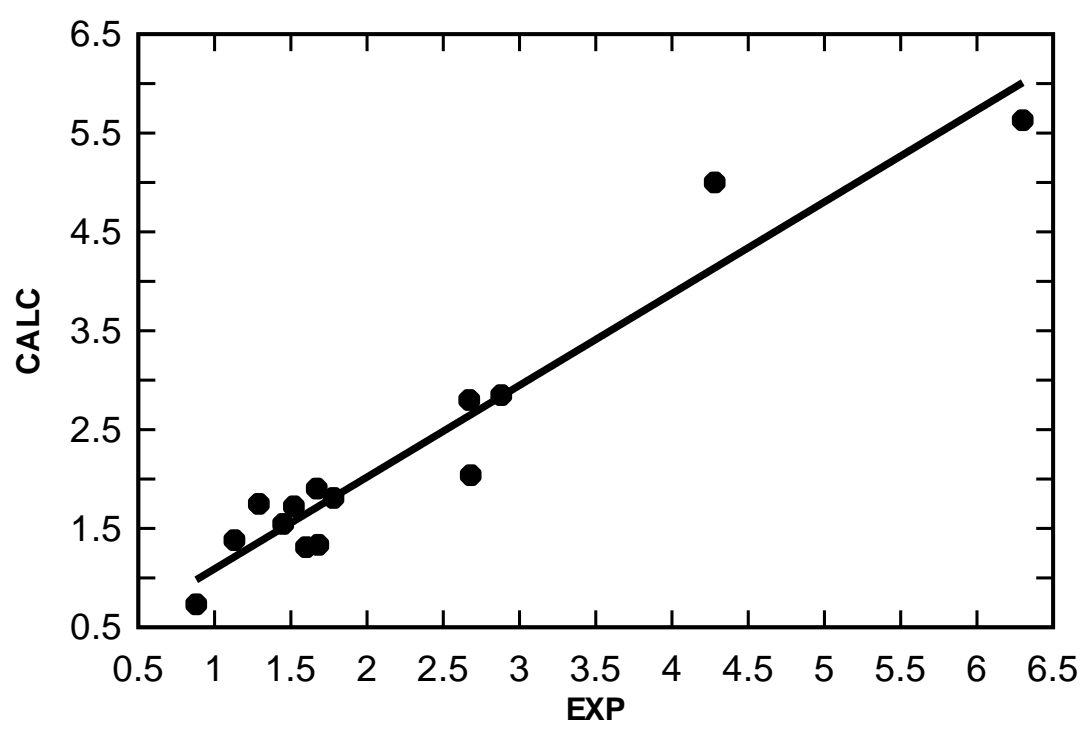

Figure 5. Plot of $(\mu)$ prediction versus $(\mu)$ experimental using Eq 4.

On other hand, when the adding of a parameters HOMO to the equation 4, obtained on equation 5. The resulting improvement of the correlation coefficient, minimum standard error and a decrease of the $F$-test statistic,. This model equation depends on the five parameters[LogP, $\quad$ surface $(\mathrm{A}), \quad \operatorname{surface}(\mathrm{G}), \quad$ T.E $\quad$ and $\mathrm{HOMO}]$. 


\section{University of Thi-Qar Journal Vol.11 No.1 Mar 2016}

Web Site: https://jutq.utq.edu.iq/index.php/main Email: journal@jutq.utq.edu.iq

D.M $=-0.642(+/-0.349) \log \mathrm{P}+0.064\left(+/-7.207 \times 10^{-2}\right) \operatorname{surface}(\mathrm{A})-3.884 \times 10^{-4}\left(+/-5.046 \times 10^{-4}\right)$

T.E- $0.0803\left(+/-9.959 \times 10^{-2} \operatorname{surface}(\mathrm{G})-0.950(+/-1.787) \mathrm{HOMO}+1.033(+/-10.156) \ldots . . . \mathrm{Eq} 5\right.$

$\mathrm{R}^{2}=0.948 \quad \mathrm{~F}=29.459 \quad \mathrm{~S}=0.423 \quad \mathrm{Ra}^{2}=0.916$

The excellent relationship between the experimental data and predicted dipole moment $(\mu)$. as shown in Fig.6.

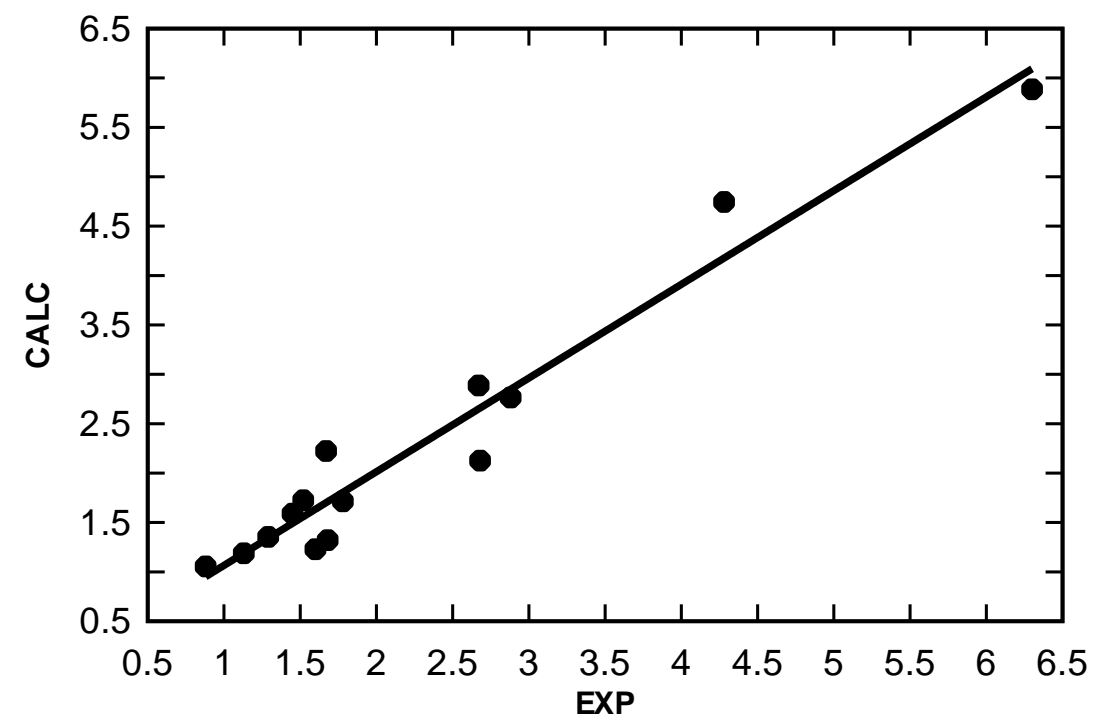

Figure 6. Plot of $(\mu)$ prediction versus $(\mu)$ experimental using Eq 5.

Excellent model equation when depends on six parameters parameters[LogP, surface(A), surface(G), T.E REF and E.GAP]. have the significant rule suggesting the importance of the substituent's on the studied compounds on the predicted dipole moment $(\mu)$. There is inverse relationship between $\log P$, T.E, Surface $(G)$ while the correlation between dipole moment and Surface(A), E.gap, Refractivity is direct relationship.

D.m $=-1.406(+/-0.679)$ LOG P+0.097(+/-7.938X10-2)surface(A) $-2.678 \times 10^{-4}\left(+/-5.749 \times 10^{-}\right.$

$\left.{ }^{4}\right)$ T.E- $0.219(+/-252)$ SURFACE $(G)+1.651(+/-1.711)$ E.GAP+0.528(+/-0.850)REF-

$0.247(+/-17.249) .$. Eq 6

$\mathrm{R}^{2}=0.972 \quad \mathrm{~F}=41.455 \quad \mathrm{~S}=0.329 \quad \mathrm{Ra}^{2}=0.949$

The excellent relationship between the experimental data and predicted dipole moment $(\mu)$ as shown in Fig.7. 


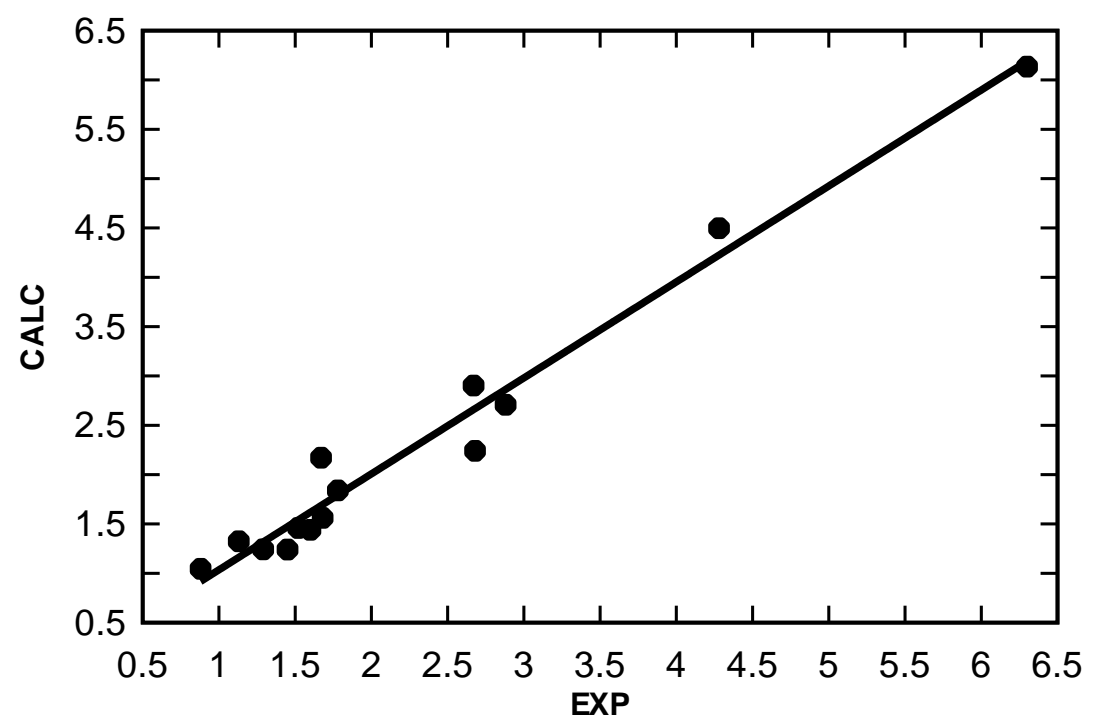

Figure 7. Plot of $(\mu)$ prediction versus $(\mu)$ experimental using Eq 6.

Consequently, among different models, The percentage of correlation coefficient $\mathrm{R}^{2}$ increased dramatically from one parameter to six parameters Eq. 1-6, which show very good correlation coefficient $\mathrm{R}^{2}$. On the other hand, after build QSPR models to predicted dipole $\operatorname{moment}(\mu)$. and the best modes was eq6 by using MP2 methods to generated geometry optimization. Also the dipole moment $(\mu)$ have been investigated for all compounds by three types of methods PM3, PM6, MP2. These method were optimized and employed to derive and predicated the dipole moment $(\mu)$ of the compounds, table 3 . It could be seen from Table 3. The predicted of the dipole moment $(\mu)$ values obtain from ( QSPR-Eq. 6 ), PM6, PM3, and MP2 in this study and comparable with the experimental values in the Reference [1]. It is obvious from this table 4 . The best value of high correlation coefficient (R), sequential Fischer test $(\mathrm{F})$, adjusted coefficient of multiple determination $\left(\mathrm{Ra}^{2}\right)$, and low standard error of estimate (S), was eq 6 , and the value calculated by MP2 method between descriptors which calculations in this study and experimental the dipole moment $(\mu)$ values are excellent.

Table 4. Predicated Experimental data depends on PM6, PM3, MP2 \& Eq 6.

\begin{tabular}{ccccc}
\hline predicted by pm6 & predicted by pm3 & predicted by mp2 & $\begin{array}{c}\text { predicted by } \\
\text { QSPR Eq 6 }\end{array}$ & \\
\cline { 1 - 4 } $\mathrm{S}=0.288$ & $\mathrm{~S}=0.511$ & $\mathrm{~S}=0.221$ & $\mathrm{~S}=0.329$ & EXP d.m \\
$\left(\mathrm{R}^{\wedge} 2\right)=0.963$ & $\left(\mathrm{R}^{\wedge} 2\right)=0.886$ & $\left(\mathrm{R}^{\wedge} 2\right)=0.978$ & $\left(\mathrm{R}^{\wedge} 2\right)=0.972$ & $\mathrm{Ref}=15$ \\
$\left(\mathrm{Ra}^{\wedge} 2\right)=0.960$ & $\left(\mathrm{Ra}^{\wedge} 2\right)=0.877$ & $\left(\mathrm{Ra}^{\wedge} 2\right)=0.976$ & $\left(\mathrm{Ra}^{\wedge} 2\right)=0.949$ & \\
$\mathrm{~F}=321.106$ & $\mathrm{~F}=94.088$ & $\mathrm{~F}=552.219$ & $\mathrm{~F}=41.455$ & \\
\hline 1.7597 & 1.5682 & 1.6057 & 1.32 & 1.13 \\
3.2 & 1.9863 & 3.0027 & 2.9 & 2.67
\end{tabular}




\section{University of Thi-Qar Journal Vol.11 No.1 Mar 2016}

Web Site: https://jutq.utq.edu.iq/index.php/main Email: journal@jutq.utq.edu.iq

$\begin{array}{lcccc}3.5246 & 1.2601 & 3.3965 & 2.7 & 2.88 \\ 2.1151 & 1.5341 & 2.0102 & 1.83 & 1.78 \\ 3.6295 & 2.34 & 3.3309 & 2.24 & 2.68 \\ 5.5544 & 5.0491 & 5.2805 & 4.49 & 4.28 \\ 8.2912 & 7.8388 & 7.7272 & 6.13 & 6.3 \\ 1.9066 & 1.3256 & 1.5355 & 1.44 & 1.6 \\ 1.5126 & 1.4518 & 1.4657 & 1.24 & 1.45 \\ 1.4839 & 1.2261 & 1.4111 & 1.45 & 1.52 \\ 3.0072 & 1.8466 & 1.2115 & 1.56 & 1.68 \\ 1.7154 & 1.1204 & 0.4719 & 1.04 & 0.88 \\ 1.696 & 1.1023 & 1.6185 & 1.24 & 1.29 \\ 2.0023 & 1.2418 & 1.4729 & 2.17 & 1.67\end{array}$

\section{Conclusion}

The quantum chemical calculations can be successfully used for the prediction of dipole moment $(\mu)$ by different methods PM6, PM3, MP2 level of theory at $6-31 \mathrm{G}(\mathrm{d}, \mathrm{p})$ basis set., is proved to be good to give the prediction of dipole moment $(\mu)$. The best predicted of the dipole moment $(\mu)$ values obtain from ( QSPR-Eq.6 ), and calculation by MP2 method. From all the results of the QSPR, the better the QSPR model was the Eq 6. have high correlation coefficient (R), sequential Fischer test (F), adjusted coefficient of multiple determination $\left(\mathrm{Ra}^{2}\right)$, and low standard error of estimate (S), As well as the dipole moment $(\mu)$ values increases with increasing the descriptors understudy including $[\operatorname{LogP}$, $\operatorname{surface}(A), \operatorname{surface}(\mathrm{G})$, T.E REF and E.GAP], Eq 6., showed insignificant role in the a predict the data of the dipole moment $(\mu)$ and these descriptors play an important role in effect on dipole moment $(\mu)$ properties of compounds, which allow chemists to elucidate and to understand how molecular structure influences properties. Through the present results exemplified here, we can apply a similar approach to build other QSPR models for dipole moment $(\mu)$ of another compounds to provide more effective means in designing novel compounds with improved profiles. This calculation procedure can be used as a model system for understanding the relationships between electronic properties and molecular structure and also can be employed to explore their suitability in different applications.

\section{References:}

1-Fay. R, McMurry. J,. Chemistry Fourth Edition, Pearson Education, New Jersey, 2004.

2-kotz, Treichel, Weaver. Chemistry and Chemical Reactivity, Thomson Brooks/Cole, 2006.

3-Gordy, W, and Cook, R. L, Microwave Molecular Spectra, Wiley, New York 1984. 


\section{University of Thi-Qar Journal Vol.11 No.1 Mar 2016}

Web Site: https://jutq.utq.edu.iq/index.php/main Email: journal@jutq.utq.edu.iq

4-Shoemaker D. P, Garland C. W and Nibler.J. W, Experiments in Physical Chemistry $8^{\text {th }}$ ed. McGraw-Hill,New York,NY, 2003.

5- Rudolf K and Márcia M. C. F., J. Braz. Chem. Soc., Vol. 20, No. 4, 770-787, 2009.

6-Alan R. K, Dan C. F, Ruslan O. P, Douglas B. T, Uko M, Andre L and Mati K., Current Topics in Medicinal Chemistry, 2, 1333-1356, 2002.

7- Davood A, Ali S, and Hossein B., Bull. Korean Chem. Soc. Vol. 29, No.10, 2008,

8-Cardoso,S. P., Gomes, J. A. C. P.., Borges, L. E. P. and Hollauer, E., Brazilian Journal of Chemical Engineering., Vol. 24, No. 04, pp. 547 - 559, October December, 2007.

9-Andrés .M , Eduardo A. C and Andrey A. T., Int. J. Mol. Sci., 2, 121-132., 2001.

10-LIU Tian-B., PENY Yan-F, and WU Xin-M., Chinese J. Struct. Chem. Vol. 26, No.12.,2007.

11-Vladyslav K, Jack R. S, Doyle Kt, Sascha A, Joachim K, and William J. W., Polymer ,45., 7367-7379., 2004.

12-Xu Hui-Y, Zou Jian-W, Hu Gui-X, and Wang W, Chemosphere ,80, 665670,2010 .

13- Frisch M. J., Trucks ,G. W., Schlegel , H. B., Scuseria, G. E., Robb, M. A., Cheeseman, J.R., Montgomery Jr, J. A., Vreven, T., Kudin, K. N., Burant, J. C., Millam ,J. M., S. S., Iyengar, J.,Barone, V., Mennucci ,B., Cossi, M., Scalmani ,G., Rega, N., Petersson ,G. A., Nakatsuji ,H., M.,Hada., Ehara M., Toyota, K., Fukuda, R., J., Ishida, M., Nakajima ,T., Honda, Y., Kitao, O., H., Klene, M., Knox, X. Li. J. E., Hratchian, H. P., Cross, J. B., Bakken, V., Adamo, C. Jaramillo, J., Gomperts, R., Stratmann, R. E., Yazyev, O., Austin, A. J., Cammi, R., Pomelli, C.,Ochterski, J. W., Ayala, P. Y., Morokuma, K., Voth, G. A., Salvador, P., Dannenberg, J. J., Zakrzewski, V. G., Dapprich, S., Daniels, A. D., Strain, M. C., Farkas, O., Malick, D. K., Rabuck, A. D., Raghavachari, K., Foresman, J. B., Ortiz, J. V., Cui, Q., Baboul, A. G., Clifford,S., Cioslowski, J., Stefanov, B. B., Liu, G., Liashenko, A., Piskorz, P., Komaromi, I., Martin, R.L., Fox, D. J., Keith, T. Gaussian Inc., Waling ford, CT, . 2004. Available on line .www .gaussian.com.

14- Lee.C., Y., W and Parr ., R. G., Phys. Rev. Lett., B37, 785-789, 1998.

15- John A. D., LANGE'S HANDBOOK OF CHEMISTRY., Fifteenth Edition,. Copyright, 1999, by McGraw-Hill, Inc.

16- XIE Ya-J., LIU Hong-X ., WANG Zun-Y., and ZHU Li-D., Chinese J. Struct. Chem.Vol. 27, No.4., 2008.

17- Ali V, Mehdi M and Farhad G., Int. J. Mol. Sci.,8, 407-432,2007.

18- Chanin N, Chartchalerm Isarankura-Na-A, Thanakorn N, and Virapong P., EXCLI Journal, 8:74-88 - ISSN 1611-2156.2009.

19- Omar D, Padmakar V. K and Mohammad G., Environmental Health Insights :4 33-47., 2010. 


\section{University of Thi-Qar Journal Vol.11 No.1 Mar 2016}

Web Site: https://jutq.utq.edu.iq/index.php/main Email: journal@jutq.utq.edu.iq

20- Pyung-Keun M and Nack-Do S., Arch Pharm Res .,Vol 30, No 8, 976-983, 2007. 